\title{
特集 器質性病变を持つてんかんの外科治療
}

\section{皮質形成異常の診断と治療}

増田浩村上博淳亀山茂樹柿田明美*

\section{Diagnosis and Treatment for Focal Cortical Dysplasia}

by

Hiroshi Masuda, M.D., Hiroatsu Murakami, M.D., Shigeki Kameyama, M.D., and Akiyoshi Kakita, M.D.*

from

Department of Neurosurgery, Epilepsy Center, Nishi-Niigata Chuo National Hospital

* Department of Pathological Neuroscience, Resource Branch for Brain Disease Research CBBR, Brain Research Institute, Niigata University

Focal cortical dysplasia (FCD) is defined as circumscribed malformation of cortical development, and it often causes medically refractory epilepsy. Palmini et al. (2004) have classified FCD into 2 types ( I and II) and 2 subtypes (A and B) each.

Of our 42 patients with FCD diagnosed pathologically, patients with type IIB had significantly more frequent seizures than patients with other types. In all patients with type IIB and 2 of 13 patients with type IIA, FCD was identified as a high signal intensity lesion on MRI ; proton-dense weighted images were more sensitive than T2 weighted images and fluid-attenuated inversion recovery images. However, FCD type IA/IB could not be identified on MRI. Chronic EEG recordings of subdural and depth electrodes disclosed frequent interictal spikes and electrical seizure onsets within FCD lesions, and these findings suggest that FCD itself has intrinsic epileptogenicity. The basic procedure of surgical treatment for FCD is multiple gyrectomy including the whole FCD lesion. In cases with negative MRI, chronic intracranial EEG recording is necessary to tailor multiple gyrectomy. In our series, all patients with FCD type IIB and $10(76.9 \%)$ of 13 patients with FCD type IIA achieved seizure freedom (Engel class I ), whereas 9 (47.4\%) of 19 patients with FCD type I were free from seizures. In conclusion, patients with MRI negative-FCD should have multimodal presurgical evaluations to more precisely delineate the lesions.

(Received December 5, 2008; accepted January 26, 2009)

Key words : epilepsy, focal cortical dysplasia, surgical treatment

$$
\text { Jpn J Neurosurg（Tokyo） } 18: 577-585,2009
$$

\section{はじめに}

限局性皮質形成異常 (focal cortical dysplasia； FCD) は, 胎生期の皮質形成期に生じた大脳皮質の構築異常を基盤 とする限局性の病変である。 1971 年に Taylor ら ${ }^{28)}$ が 10 例のてんかん患者の手術標本でみられた病変を報告した
のをはじめとし，難治性てんかんの原因病変として注目 されるようになった，Taylor らが報告したのは，皮質構 造のみならず，強い細胞形態異常を伴ったものであった が，その後細胞形態異常のない皮質構築の異常のみのも のも報告されるようになり, microdysgenesis ${ }^{14)}$ なる用語 も使われ混乱がみられた。 Palmini ら ${ }^{21)}$ は, 1994 年に

国立病院機構西新潟中央病院てんかんセンター脳神経外科 / T950-2085 新潟市西区真砂 1-14-1〔連絡先：増田 浩〕 Address reprint requests to: Hiroshi Masuda, M.D., Department of Neurosurgery, Epilepsy Center, Nishi-Niigata Chuo National Hospital, 1-14-1 Masago, Nishi-ku, Niigata-shi, Niigata 950-2085, Japan

* 新潟大学脳研究所脳疾患リソース解析部門 
grade I 〜IIIに分類したが，その後 2004 年に新たな分類 を示し, 現在はこの分類が用いられることが多い23). Palmini らは，FCD を皮質構築異常のみを認める type I と dysmorphic neuronを伴う type II に分け, type I は皮質 構築異常のみの IA と immature neuron や giant neuron などの幼若細胞の遺残を認める IB に, type II を dysmorphic neuronのみの IIA とそこに balloon cell を認める IIB に分類した。ささに FCD よりさらに軽微な異常を持つ ものを mild MCD (malformation of cortical development) として分けている。従来 Taylor type FCD と呼ばれてい たものは type II に相当し, microdysgenesis と呼ばれてい たものは， mild MCD から type IA に相当する。

FCD は難治性てんかんの原因病変としては海馬硬化 に次いで頻度が高く,てんかん手術例の $20 \%$ 程度を占め るとされる ${ }^{15)}$. FCD はそれ自体がてんかん原性を持って いることが特徴であり (intrinsic epileptogenesity ${ }^{22)}$ ), 他 のてんかん原性病変と異なる点である，例えば, dysembryoplastic neuroepithelial tumor(DNT)などの mixed neuronal-glial tumor や結節性硬化症における皮質結節など は代表的なてんかん原性病変であるが，硬膜下電極や深 部電極による検討では，発作時は周辺の脳から発作発射 が起こる，つまり，これら病変自体にはてんかん原性は なく, これら病変の近傍に併存する $\mathrm{FCD}$ がこれら病変 の真のてんかん原と考えられる ${ }^{910)}$.

本稿では, 自験例の臨床像, 検査所見, 手術法と病理 組織診断, 発作転帰について後方視的に検討し.FCD の 診断と治療について考察する。

\section{対 象}

症例は，西新潟中央病院てんかんセンターにおいて， 1997 年 12 月〜2007 年 11 月までに焦点切除術が施行さ れ, 病理組織学的に Palmini の分類 (2004) に従って FCD と診断された 42 例（男性 28 例, 女性 14 例）で, 手術 時平均年齢は 26.0 (3〜 58) 歳である. 病理診断は IA 15 例, IB 4 例, IIA 13 例, IIB 10 例であったので, IA と IB を合わせ IA/IB として, 3 群で比較検討した。

\section{結 果}

\section{1 臨床像}

自験例 41 例の病理分類別の臨床像を Table 1 に示す. 発症年齢は IA/IB に比し，IIA，IIB が有意に低かった (IIA 群 $p<0.05$, IIB 群 $p<0.005, t$-test). 手術前の発 作頻度は, IA/IB 群が平均 10.2 回/月, IIA 群が 19.4 回/
月なのに対し, IIB 群は 174.5 回/月と有意に $(p<0.05)$ 多 く, IIB 群は日単位の発作を呈する例がほとんどで, 日 に 10 回以上の発作をきたすものも 3 例あった. IIA 群も IIB 群ほどではないが発作頻度が高く, 12 例中 5 例で日 単位の発作を呈していた。一方, IA/IB 群では発作頻 度は多くて週単位であり, 月単位のものも多かった。

てんかん分類と病理分類を比較すると, IA/IB は側頭 葉てんかん (temporal lobe epilepsy；TLE) が $68.2 \%$ と多 いのに対し, IIB は前頭葉てんかん (frontal lobe epilepsy； FLE）が $80 \%$ と多かった（Table 1).

2 脳波, 脳磁図 (magnetoencephalography; MEG) 発作間欠期の頭皮脳波では，ほぼ全例で FCD の局在 に一致した部位に棘波が認められたが, FCD が大脳半球 間裂に存在した 2 例で棘波を認めなかった。 また TLE 20 例中 8 例で両側性の來波が認められた. 発作時脳波で は, FLE 17 例中 15 例で発作とともに筋電図が混入し, 局 在はおろか左右の判定すらできなかった．TLEでは 20 例中 5 例で左右どちらの起始か判定ができなかった。

MEG は 2000 年 4 月に導入され，31 例で施行された (IIB 6 例, IIA 11 例, IA/IB 14 例)。 IIB では 6 例全 例 FCD に一致した等価電流双極子 (equivalent current dipole；ECD）の集積が認められた. IIA では 11 例中 10 例で FCD を中心とした ECD の集積が認められたが, や や広い範囲に広がっている傾向を示した。 IA/IB では ECD は集積せず広い範囲に散在するものがほとんどで あった。

\section{3 画像診断}

MRI で FCD を検出できたものは, IIB 群では 10 例全 例, IIA 群では 13 例中 2 例で, IA/IB 群では全例異常 所見を認めなかった.

発作間欠期脳血流 SPECT では, IIB のうち病変が比較 的大きなものでは病変に相当する部分の血流低下所見 が 4 例に認められたが, IIA, IA/IB 群では明らかな低 下所見を認めた例はなかった。発作時 SPECT はIIB と IIA ではそれぞれ 9 例 12 回, IA/IB では 9 例 14 回施 行された，発作時から発作間欠時をサブトラクションし て MRI 画像に重畳する subtraction ictal SPECT co-registered to MRI（SISCOM）で画像処理を行うと，IIBの 9 例 12 回中 8 例 11 回で病変部に一致した血流増加が認 められた. IIA では 7 例 10 回で切除部に一致した血流増 加が認められたが, IA/IB で切除部に一致した血流増加 が認められたのは 2 例 2 回のみであった. 2004 年 6 月か ら中枢性ベンゾジアゼピン受容体のトレーサーである 
Table 1 Clinical feature and types of focal cortical dysplasia

\begin{tabular}{cccc}
\hline Clinical feature & $\begin{array}{c}\text { IA/IB } \\
(n=19)\end{array}$ & $\begin{array}{c}\text { IIA } \\
(n=13)\end{array}$ & $\begin{array}{c}\text { IIB } \\
(n=10)\end{array}$ \\
\hline $\begin{array}{c}\text { Sex (male : female) } \\
\text { Age at operation } \\
\text { (years) }\end{array}$ & $12: 7$ & $10: 3$ & $6: 4$ \\
$\begin{array}{c}\text { Age at seizure onset } \\
\text { (years) }\end{array}$ & $11.7 \pm 11.9$ & $21.2 \pm 8.1^{*}$ & $21.9 \pm 17.1$ \\
$\begin{array}{c}\text { Epilepsy history } \\
\text { (years) }\end{array}$ & $19.4 \pm 12.4$ & $13.9 \pm 6.8$ & $15.8 \pm 12.9$ \\
$\begin{array}{c}\text { Seizure frequency } \\
\text { (times per month) }\end{array}$ & $10.5 \pm 16.2$ & $19.0 \pm 17.4^{*}$ & $174.5 \pm 190.7^{* \dagger}$ \\
$\begin{array}{c}\text { Epilepsy type } \\
\text { FLE }\end{array}$ & 4 & & \\
TLE & $(21.1 \%)$ & $(38.5 \%)$ & $(80.0 \%)$ \\
Others & 14 & 6 & 1 \\
& $(73.7 \%)$ & $(46.2 \%)$ & $(10.0 \%)$ \\
& 1 & 2 & 1 \\
& $(5.3 \%)$ & $(15.4 \%)$ & $(10.0 \%)$ \\
\hline
\end{tabular}

The age at operation was significantly younger in the type IIA group than in the type IA/IB group $\left({ }^{*}: p<0.05, t\right.$-test $)$. The age at seizure onset was significantly younger in the IIB group than in the type IA/IB group $\left(^{*}: p<\right.$ $0.05, t$-test). Epilepsy history was not sig-nificantly different among 3 groups. Seizure fre-quency was significantly higher in the type IIB group than in either the type IIA group $\left({ }^{\dagger}: p<0.05, t\right.$-test $)$ and IA/IB group $\left(^{*}\right.$ : $p<0.05, t$-test), and seizure frequency was sig-nificantly higher in the type IIA group than in the type IA/IB group $\left({ }^{*}: p<0.05, t\right.$-test $)$. mean \pm S. D., FLE; frontal lobe epilepsy, TLE; temporal lobe epilepsy

Table 2 Seizure outcomes and types of FCD

\begin{tabular}{ccccc}
\hline $\begin{array}{c}\text { Engel's } \\
\text { classification }\end{array}$ & $\begin{array}{c}\text { IA/IB } \\
(n=19)\end{array}$ & $\begin{array}{c}\text { IIA } \\
(n=13)\end{array}$ & $\begin{array}{c}\text { IIB } \\
(n=10)\end{array}$ & $\begin{array}{c}\text { Total } \\
(n=42)\end{array}$ \\
\hline Class I & 9 & 10 & 10 & 29 \\
& $(47.4 \%)$ & $(76.9 \%)$ & $(100 \%)^{*}$ & $(69.0 \%)$ \\
Class II & 2 & 0 & 0 & 2 \\
& $(10.5 \%)$ & & & $(4.8 \%)$ \\
Class III & 7 & 3 & 0 & 10 \\
& $(36.8 \%)$ & $(23.1 \%)$ & & $(23.8 \%)$ \\
Class IV & 1 & 0 & 0 & 1 \\
& $(5.3 \%)$ & & & $(2.4 \%)$ \\
\hline
\end{tabular}

More patient achieved a class I outcome in the type IIB group than in the type IA/ IB group $\left(^{*}: p<0.005\right.$, Chi-square test $)$.

iomazenil を用いた ${ }^{123}$ I-iomazenil (IMZ) SPECT が行える ようになり，17 例（IIB 4 例, IIA 7 例, IA/IB 6 例）で 施行された。結果を asymmetry index (AI) を計算し MRI 画像上に結果を表示する AI map (Focus Viewer ${ }^{\circledR}$ ：日本 メジフィジクス社）および three dimensional stereotactic surface projection（3D-SSP：Minoshima ら）による統計 画像解析を行うと, IIB は 3 例 $(75 \%)$, IIA は 3 例 (42.9\%)，IA/IB は 3 例（50\%）で RI 取り込み低下部
位が FCD の局在に一致した。

\section{4 慢性頭蓋内脳波記録}

39 例で慢性頭蓋内脳波記録を行った. 初回の記録で発 作起始を捉えられずに，電極の再留置を行ったものが 3 例，当初より複数回の記録を計画して行ったものが 1 例 (3 回), いったん焦点切除手術を行ったが発作が残存し, 再度記録を行ったものが 2 例あった。IIB での電極の入 

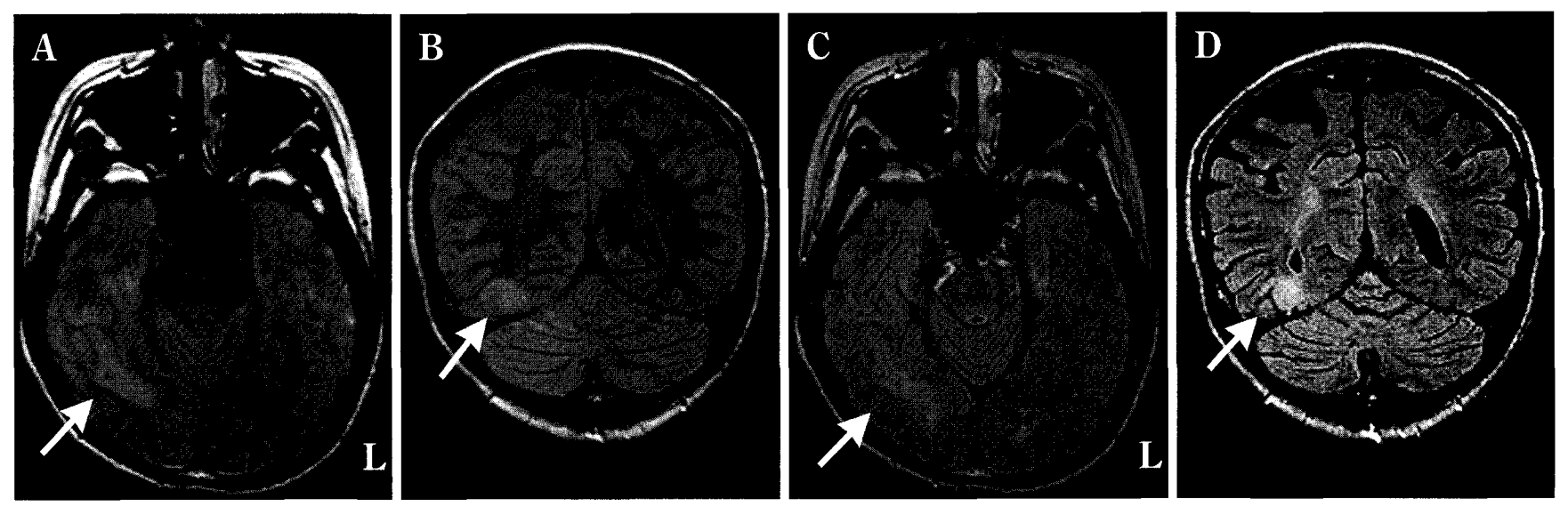

Fig. 1 Representative MR images of type IIB FCD are shown. Axial (A) and coronal（B） images on proton-dense weighted MRI show a hyperintense lesion (arrows) in the right temporo-occipital base, which are more distinctive than the fluid attenuated inversion recovery images $(\mathbf{C}:$ axial, $\mathbf{D}:$ coronal) obtained from a 23 -yearold woman.
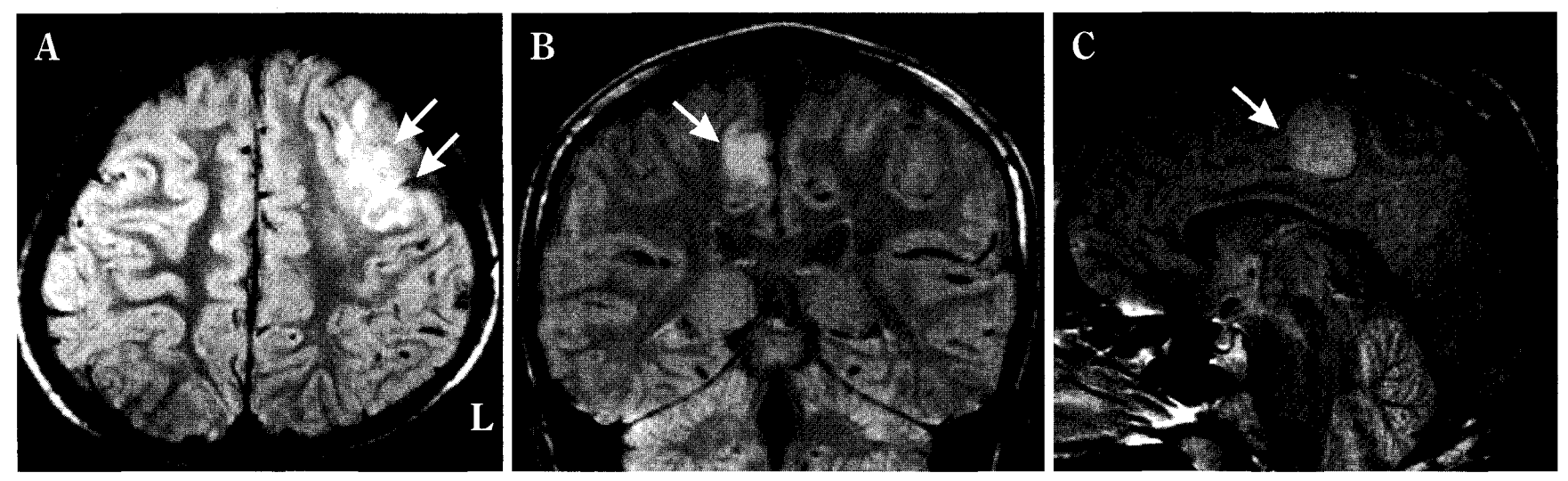

Fig. 2 Proton-dense weighted MR images of gyral core pattern FCD show hyperintense lesions (arrows) involving multiple gyri.

A : FCD type IIB, A 4-year-old girl.

B : FCD type IIB, A 9-year-old boy.

C : FCD type IIA, A 18-year-old man.

れ直しも 1 例あり，硬膜下電極のみでは発作起始を捉え られず，深部電極を入れてようやく発作起始を捉えられ た例であった．IIB 群では記録を行った 7 例全例で FCD 上の硬膜下電極または FCD 内に入れた深部電極から発 作起始が記録された。

\section{5 焦点切除術}

42 例に対し 48 回の手術が施行された。 IIB では 1 例 で 3 回, 1 例で 2 回の切除術が行われたが, いずれも当 院での初期の手術症例で, 病変の切除が不十分であった ために発作が残存したものであった。これ以外の 8 例で は病変の全摘出が行われた. IIA では 1 例が病変の全摘 出(MRI で病変が認められた症例), 2 例が前側頭葉切除, 扁桃体海馬切除に加え外側皮質の皮質切除, 2 例が前側
頭葉切除 (海馬温存)，2 例で Broca 野に焦点が同定され たため, 周辺の皮質切除に Broca 野の軟膜下皮質多切術 (multiple subpial transection；MST) を行い, 他の 6 例は 皮質切除を行った. IA/IB では 7 例で前側頭葉切除 (海 馬温存), 1 例で前側頭葉切除, 扁桃体海馬切除, 他 11 例は皮質切除を行った。

\section{6 発作転帰}

IIB は 10 例全例, IIA 13 例中 10 例 (76.9\%) が Engel class I であったが, type IA/IB では Engel class I は 19 例中 9 例 $(47.4 \%)$ であった（Table 2). 

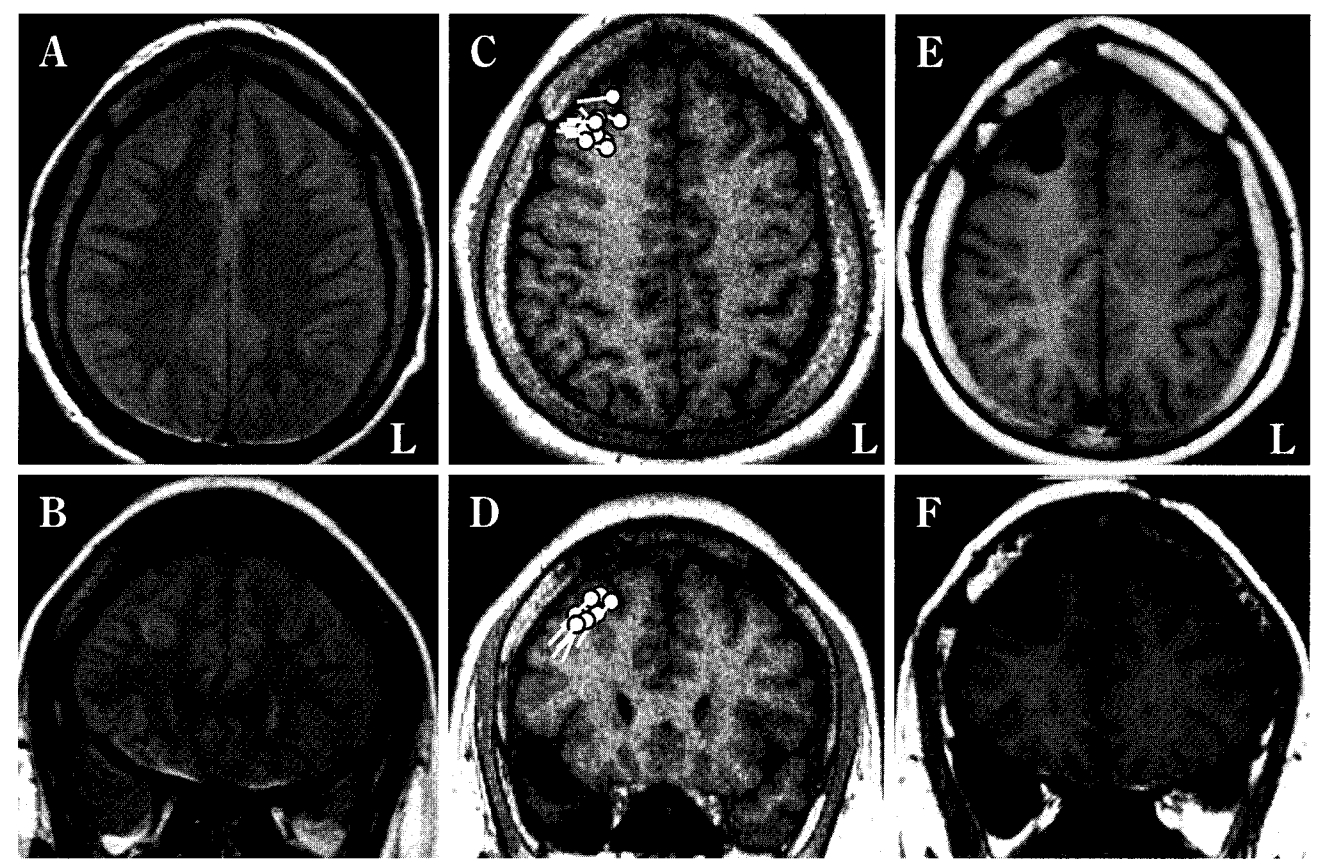

Fig. 3 Axial (A) and coronal (B) images on proton-dense weighted MRI show sulcal island pattern FCD type IIB (arrows) in a 30-year-old man. Axial (C) and coronal (D) magnetic source images demonstrate a single cluster of equivalent current dipole just within the FCD. Postoperative axial (E) and coronal (F) images on T1-weighted MRI show brain defect after gyrectomy.

\section{考 察}

\section{1 診断}

FCD の診断では最も MRI が有用である. FCD の MRI 所見の特徵として, (1)局所的な皮質の肥厚, (2)皮髄境界 の不鮮明化, (3)T2 強調画像, fluid-attenuated inversion recovery (FLAIR) 画像およびプロトン密度強調画像 (proton-dense weighted image；PDWI）における皮質下白質 を含む高信号病変が挙げられる377)16242430). 中でも FLAIR 画像が有用であるという報告が多いが7299) 31), わ れわれの経験では, FLAIR より PDWI のほうが視認性が 良好で病変の広がりがよくわかる30) と考えている（Fig. 1). 通常のルーチン検査では PDWI が行われることが少 ないが，てんかんの画像診断を行う場合は PDWI を加兄 て撮影するのがよい.FCD の信号変化は微細なことが多 く ${ }^{16)}$ ， あまり薄いスライスで撮像するとその変化がわか りにくくなるので, やや厚めのスライス $(5 \sim 6 \mathrm{~mm})$ で 撮像するほうが視認性がよい。 また(1)，(2)については，

3D 画像, T2 強調画像や short-T1 inversion recovery （STIR）画像を白黒反転させた画像が，皮質と白質のコ ントラストが強くなり判別が容易になる。 また, 画像処 理によって微細な変化を検出する方法も報告されてい $る^{1 / 4) 6)}$.
(3)の高信号病変は，一つまたはそれ以上の脳回全体が 高信号を呈する “gyral core” パターン（Fig. 2）と，脳 溝の深部の皮質が肥厚し皮質下白質とともに高信号を呈 する "sulcal island” パターン（Fig. 3〜5）に分けられる. この用語はもともと結節性硬化症の皮質結節でみられる パターンを示したものであるが18)，FCD でも同様のパ ターンが当てはまる.自験例の MRI で高信号病変を呈し た 12 例では, gyral core パターンが 7 例, sulcal island パターンが 5 例であった。この他にも, FCD から脳室壁 へ索状の高信号が伸びていることも多く（transmantle dysplasia $\left.^{2)}\right)$ ，これも皮質結節と類似した点である。皮質 結節ではしばしば多発病変となるため鑑別は比較的容易 であるが，FCD は PDWI のほうが FLAIR より視認性が よいのに対し，皮質結節はむしろ FLAIR のほうが視認性 がよいことが鑑別点として挙げられる ${ }^{30)}$.

しかし，実際には MRIで描出されない FCD のほうが 多く,この MRI で描出されない FCD の局在診断が問題 となる，脳波である程度の局在を推定できる場合もある が, FLEでは発作時脳波があまり参考にならないことが 多く ${ }^{15)}$, TLE でも両側性の間欠期棘波や，発作時にも左 右差の判別が困難な例も多い.このような例では MEG が有用である.MEG は ECD を MRI に重畳して表示でき る magnetic source image (MSI) が有用である（Fig.3）. 

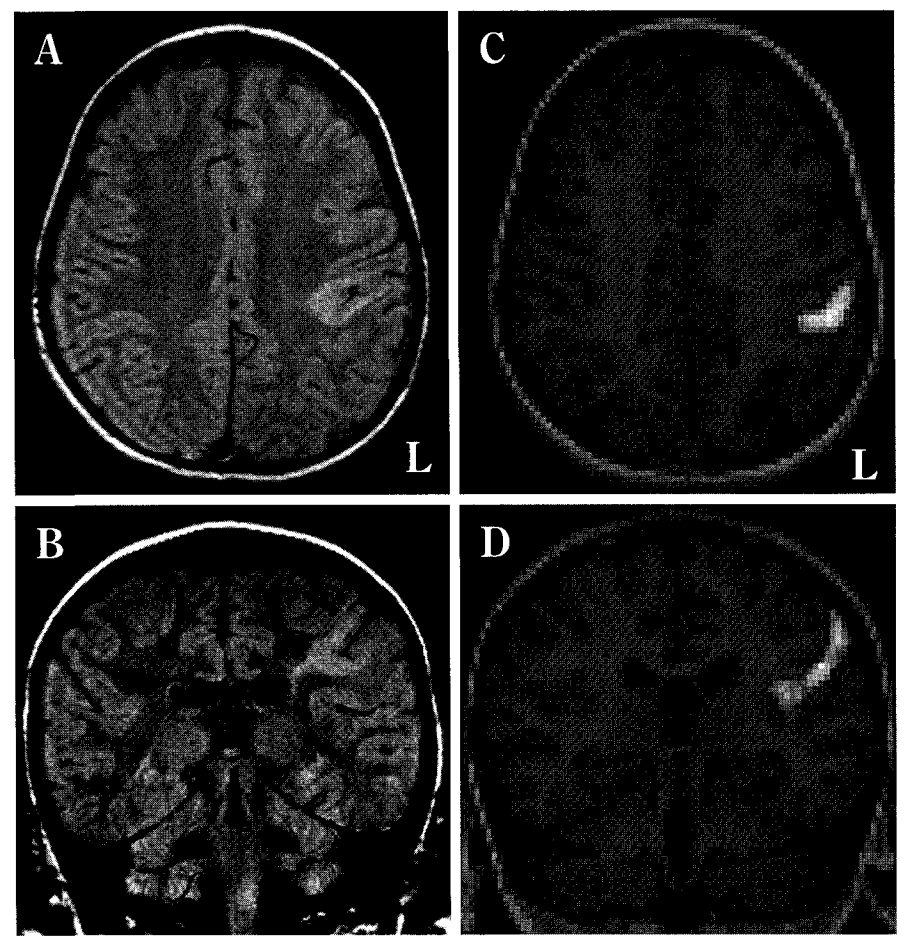

Fig. 4 Axial (A) and coronal (B) images on proton-dense weighted MRI show sulcal island pattern FCD type IIB with transmantle dysplasia around the left postcentral sulcus in a 3-year-old boy. Axial (C) and coronal (D) images of subtraction ictal SPECT co-registered to MRI (SISCOM) demonstrate a hyperperfused area corresponding to the MRI abnormality.
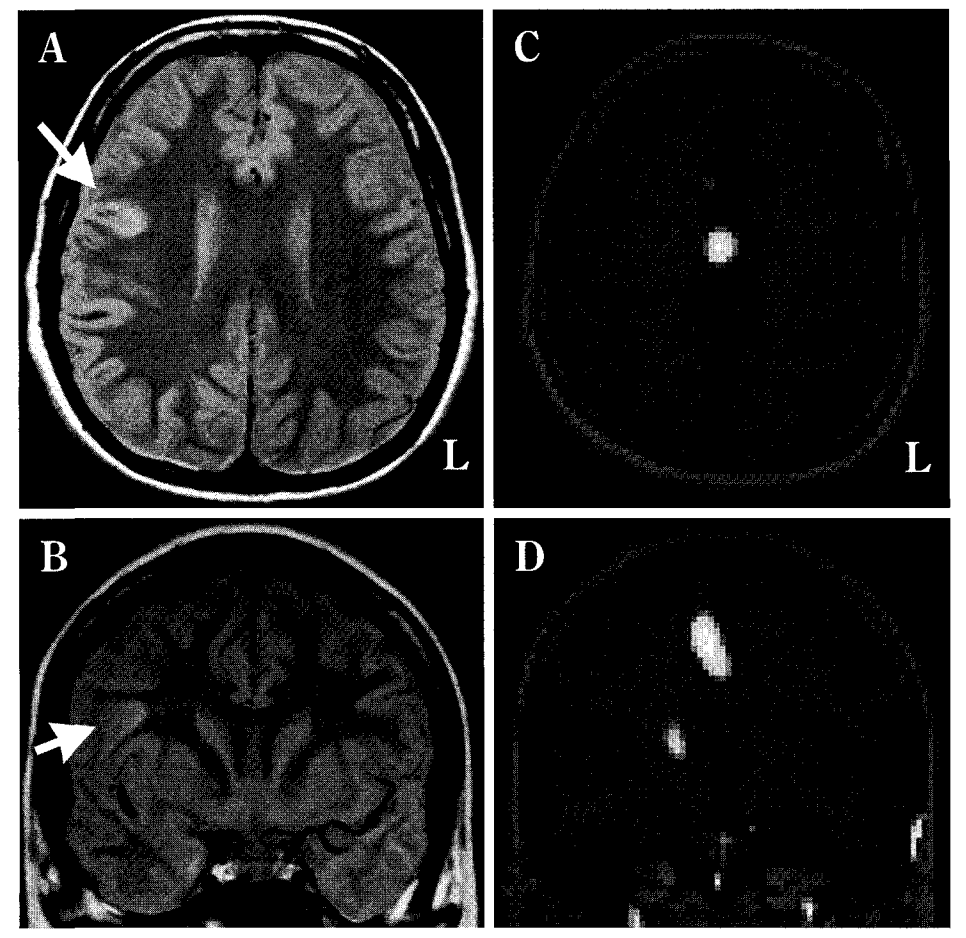

Fig. 5 Axial (A) and coronal (B) images on protondense weighted MRI show sulcal island pattern FCD type IIB (arrow) in a 20-year-old woman. Axial (C) and coronal (D) subtraction ictal SPECT co-registered to MRI (SISCOM) images demonstrate a hyperperfusion area in the right cingulate gyrus, discordant with the FCD, which is thought to be the symptomatogenic zone.
われわれは，三次元再構成した MRI の脳表画像に ECD を乗せた 3D-MSI を作製し, 硬膜下電極や深部電極の設 置術の際のガイドとして使用している.

もう一つ FCDの局在を推定するのに役立つのが SPECT である。現在てんかん診断に用いられているの は, ${ }^{123} \mathrm{I}-\mathrm{IMP}$ (iodeamphetamine), ${ }^{99 \mathrm{~m}} \mathrm{Tc}-\mathrm{ECD}$ (ethyl cytein- ate dimer), ${ }^{99 m} \mathrm{Tc}-\mathrm{HMPAO}$ (hexamethlypropyleneamine oxime）を用いた脳血流 SPECT と中枢性ベンゾジアゼピ ン受容体のトレーサーであるイオマゼニルを用いた ${ }^{123} \mathrm{I}-$ IMZ SPECT である. 脳血流 SPECT では, 発作間欠期に は MRI の病変部に一致して脳血流低下を示すとされて いるが12)26), その変化は軽微で通常の視察では判断が困 
難なことが少なくない．また，発作頻度が多い場合には FCD 内部の活発な発作活動のため血流低下を示さな かったり，時に病変部が高灌流となることもしばしば経 験する．脳血流 SPECT では発作間欠時の検査のみなら ず，発作時に血流が増加した部位を検出し，診断する発 作時 SPECT が最も焦点の検出率が高い20). 発作時の データから発作間欠時のデータをサブトラクションして 血流増加部位を統計学的に計算し，さらに患者自身の MRI 画像に重畳して表示する SISCOM $^{13) 19)}$ を用いると, MRI 病変との一致が明膫に描出され (Fig. 4)，また, MRI で病変が認められない場合の焦点診断に有用である。し かし，FLEでは時に発作起始からすぐに帯状回に発作が 伝播し, 焦点と離れた場所（発作発現部位 symptomatogenic zone）が高灌流となることがあるため注意を要す る ${ }^{13)}$ （Fig. 5)。また特に SISCOM を行う際には，発作間 欠時の SPECT が頻回の発作のために正常あるいは高灌 流となっている場合には，焦点をうまく検出できないこ とがあり, 間欠期の検査時にはミダゾラムやジアゼパム を静注して発作活動を抑制して，検査を行うことが望ま しいと考えている.

てんかん焦点では中枢性ベンゾジアゼピン受容体が減 少しているとされ ${ }^{17) 27)}$ ，この受容体の減少を検出するの が IMZ-SPECT である. FCD においては MRI で描出さ れるようなものでは, IMZ-SPECT においても RI 取り込 み低下として描出されるが，MRI で描出されない FCD ではその所見は必ずしも明瞭ではない，3D-SSPや AI map などの統計画像解析を用いてようやく検出が可能で あるものも多く, IMZ-SPECT の評価には統計画像解析 が必須である.しかし,中にはこれら統計画像解析を行っ てもなお検出が困難なものもあることには注意が必要で ある。

当院では設備がないため経験がないが，positron emission tomography (PET), 特に ${ }^{18} \mathrm{~F}$-fluorodeoxyglucose (FDG) PET では約 70\%の症例で FCD は代謝低下域として描出 される25).

\section{2 慢性頭蓋内脳波記録}

今回の症例で慢性頭蓋内脳波記録を施行しなかった 3 例は, MRI や MEG 所見から FCD（type IIB）と診断 できたものであり, MRI で病変が認められないものでは 慢性頭蓋内脳波記録は必須である.病変が MRI で認めら れても，特に機能野近傍の FCD の場合は皮質機能マッ ピングを行う必要があるので, やはり頭蓋内電極留置は 必須である ${ }^{5) 16)}$ ．硬膜下電極を基本とするが,特に“sulcal island”タイプの FCD では脳表で発作活動を捕捉しにく
い場合もあり，深部電極が有用である。

Type IIB の FCD では, 発作間欠期においても硬膜下電 極または深部電極から高頻度の棘波が認められ，発作時 には FCD 内部からの発作起始が確認できる.MRI で病 変が認められないものでは，脳波，MEG，SPECT など あらゆる術前検查を駆使して焦点の局在を推定し，それ を中心に可能な限り広範囲に電極を留置することが必要 である。一方，術中に得られた皮質脳波記録での棘波は 必ずしも焦点を示さず，術中まったく棘波がなかった場 所から発作が起始することもまれではないので注意が必 要である。

\section{3 焦点切除術}

われわれは脳回を単位とし，FCD を含むすべての脳回 の裁断的軟膜下脳回切除を基本としている（Fig. 3). MRI で病変を認める FCD は肉眼的にも白色調の強い硬 い組織として認められる，正常な脳組織が認められるま で病変を完全に切除することがよい発作転帰につなが $3^{8) 16)}$. Type IIB の FCD ではその内部に正常な脳機能は ないとされているが11)，IIAの FCD では機能を持ってい ることがある，手，足の運動野，言語野（Broca 野また は Wernicke 野) に存在する場合は MST を行うが, 発作 の抑制率は切除に比べて不良である ${ }^{8)}$.

\section{4 発作転帰}

MRI で描出されるIIB の転帰が良好であるのは当然と しても, 多くが MRI で描出されない IIA でも転帰は良好 である. 自験例での IIA で Engel class 3 の 3 例中 2 例は Broca 野に焦点が同定され MST を行った症例である。一 方で IA/IB の発作転帰は全般的に不良であり，これら $\mathrm{IA} / \mathrm{IB}$ 症例の手術成績の向上が今後の重要な課題であ る.今回の検討で type IIA と IA/IB との間に発作頻度の 差や MEG 上の双極子の分布などの臨床所見上明らかな 差異が認められたことから，同じMRI で描出されない例 でも，非侵襲的検査の段階である程度病理分類の予測が 可能であり，IA/IB が予測される場合にはあらゆる術前 の検査手段を用いた，より慎重な焦点局在診断が必要と なると思方机る。

\section{まとめ}

FCD は MRI の PDWI と FLAIR 画像で高信号病変と して描出され, 病変の完全切除でよい発作転帰が期待で きる。しかし，MRIで描出されないものは，あらゆる検 查手段を駆使して局在診断を行う必要がある。特に 
MEG と発作時 SPECT が有用であり，それらの結果に基 づいて硬膜下電極，必要なら深部電極を留置し慢性頭蓋 内脳波記録を行って切除範囲を決定する必要がある。

\section{文 献}

1) Antel SB, Bernasconi A, Bernasconi N, Collins DL, Kearney RE, Shinghal R, Arnold DL: Computational models of MRI characteristics of focal cortical dysplasia improve lesion detection. NeuroImage 17: 1755-1760, 2002.

2) Barkovich AJ, Kuzniecky RI, Bollen AW, Grant PE : Focal transmantle dysplasia: A specific malformation of cortical development. Neurology 49: 1148-1152, 1997.

3) Bast T, Ramantani G, Seitz A, Rating D: Focal cortical dysplasia: Prevalence, clinical presentation and epilepsy in children and adults. Acta Neurol Scand 113: 72-81, 2006.

4) Bernasconi $\mathrm{A}$ : Advanced MRI analysis methods for detection of focal cortical dysplasia. Epileptic Disord 5 (Suppl 2) : S81-84, 2003.

5) Bingaman WE : Surgery for focal cortical dysplasia. Neurology 62 (Suppl 3) : S30-34, 2004.

6) Colliot O, Bernasconi N, Khalili N, Antel SB, Naessens V, Bernasconi A : Individual voxel-based analysis of gray matter in focal cortical dysplasia. NeuroImage 29:162-171, 2006.

7) Colombo N, Tassi L, Galli C, Citterio A, Lo Russo G, Scialfa G, Spreafico R: Focal cortical dysplasias : MR imaging, histopathologic, and clinical correlations in surgically treated patients with epilepsy. AJNR Am J Neuroradiol 24: 724-733, 2003.

8) Hader WJ, Mackay M, Otsubo H, Chitoku S, Weiss S, Becker L, Snead OC 3rd, Rutka JT: Cortical dysplastic lesions in children with intractable epilepsy : Role of complete resection. J Neurosurg 100 (2 Suppl Pediatrics): 110-117, 2004.

9）亀山茂樹，柿田明美：てんかんの画像と病理 4. 結節性 硬化症. No Shinkei Geka 35：1027-1035， 2007.

10) Kameyama S, Fukuda M, Tomikawa M, Morota N, Oishi M, Wachi M, Kanazawa O, Sasagawa M, Kakita A, Takahashi $\mathrm{H}$ : Surgical strategy and outcomes for epileptic patients with focal cortical dysplasia or dysembryoplastic neuroepithelial tumor. Epilepsia 42 (Suppl 6) :37-41, 2001.

11) Marusic P, Najm IM, Ying Z, Prayson R, Rona S, Nair D, Hadar E, Kotagal P, Bej MD, Wyllie E, Bingaman W, Lüders $\mathrm{H}$ : Focal cortical dysplasias in eloquent cortex: Functional characteristics and correlation with MRI and histopathologic changes. Epilepsia 43: 27-32, 2002.

12) Matsuda K, Mihara T, Tottori T, Otubo T, Usui N, Baba K, Matsuyama N, Yagi K: Neuroradiologic findings in focal cortical dysplasia: Histologic correlation with surgically resected specimens. Epilepsia 42 (Suppl 6) : 29-36, 2001.

13) Matsuda H, Matsuda $K$, Nakamura F, Kameyama S, Masuda H, Otsuki T, Nakama H, Shamoto H, Nakazato N, Mizobuchi M, Nakagawara J, Norioka T, Kuwabara Y, Aiba H, Yano M, Kim YJ, Nakase H, Kuji I, Hirata Y, Mizumura $\mathrm{S}$, Imabayashi E, Sato N : Contribution of subtraction ictal SPECT coregistered to MRI to epilepsy surgery : A multicenter study. Ann Nucl Med 23: 283-291, 2009.

14) Meencke $\mathrm{HJ}$ : The density of dystopic neurons in the white matter of the gyrus frontalis inferior in epilepsies. J Neurol
230: 171-181, 1983.

15）三原忠紘，松田一已，鳥取孝安，大坪俊昭，久保田裕子, 井上有史, 渡辺裕貴, 日吉俊雄, 八木和一: Focal cortical dysplasia とてんかん外科. 脳と発達 29: 134-144, 1997.

16）森岡隆人, 西尾俊嗣, 福井仁士: 皮質形成異常（cortical dysplasia), 特に限局性皮質形成異常 (focal cortical dysplasia) とてんかん. No Shinkei Geka 27:605-615, 1999.

17) Morimoto K, Tamagami H, Matsuda K: Central-type benzodiazepine receptors and epileptogenesis: Basic mechanisms and clinical validity. Epilepsia 46 (Suppl 5) : 184188, 2005.

18) Nixon JR, Houser OW, Gomez MR, Okazaki H: Cerebral tuberous sclerosis: MR imaging. Radiology 170:869$873,1989$.

19) O'Brien TJ, So EL, Mullan BP, Hauser MF, Brinkmann BH, Bohnen NI, Hanson D, Cascino GD, Jack CR Jr, Sharbrough FW: Subtraction ictal SPECT co-registered to MRI improves clinical usefulness of SPECT in localizing the surgical seizure focus. Neurology $\mathbf{5 0}: 445-454,1998$.

20) Otsuki $T$ : Neuroimaging and presurgical evaluation of symptomatic epilepsies. Psychiatry Clin Neurosci 58: S13-15, 2004.

21) Palmini A, Gambardella A, Andermann F, Dubeau F, da Costa JC, Olivier A, Tampieri D, Robitaille Y, Paglioli E, Paglioli-Neto E, Coutinho L, Kim HI: Operative strategies for patients with cortical dysplastic lesions and intractable epilepsy. Epilepsia 35 (Suppl 6) : S57-71, 1994.

22) Palmini A, Gambardella A, Andermann F, Dubeau F, Costa JC, Olivier A, Tampieri D, Gloor P, Quesney F, Andermann E, Paglioli E, Paglioli-Neto E, Coutinho L, Leblanc R, Kim $\mathrm{JI}$ : Intrinsic epileptogenicity of himan dysplastic cortex as suggested by corticography and surgical results. Ann Neurol $37: 476-487,1995$.

23) Palmini A, Najm I, Avanzini G, Babb T, Guerrini R, Foldvary-Schaefer N, Jackson G, Lüeders HO, Prayson R, Spreafico R, Vinters HV: Terminology and classification of the cortical dysplasias. Neurology 62 (Suppl 3) : S2-8, 2004.

24) Raybaud C, Shroff M, Rutka JT, Chuang SH : Imaging surgical epilepsy in children. Childs Nerv Syst 22: 786-809, 2006.

25) Salamon N, Kung J, Shaw SJ, Koo J, Koh S, Wu JY, Lerner JT, Sankar R, Shields WD, Engel J Jr, Fried I, Miyata H, Yong WH, Vinters HV, Mathern GW: FDG-PET/MRI coregistration improves detection of cortical dysplasia in patients with epilepsy. Neurology 71 : 1594-1601, 2008.

26) Sasaki K, Ohsawa Y, Sasaki M, Kaga M, Takashima S, Matsuda $\mathrm{H}$ : Cerebral cortical dysplasia : Assessment by MRI and SPECT. Pediatr Neurol 23:410-415, 2000.

27) Tanaka F, Yonekura Y, Ikeda A, Terada K, Mikuni N, Nishizawa S, Ishizu K, Okazawa H, Hattori N, Shibasaki H, Konishi J, Onishi Y: Presurgical identification of epileptic foci with iodine-123 iomazenil SPET : comparison with brain perfusion SPET and FDG PET. Eur J Nucl Med 24:2734, 1997.

28) Taylor DC, Falconer MA, Bruton CJ, Corsellis JA: Focal dysplasia of the cerebral cortex in epilepsy. J Neurol Neurosurg Psychiatry 34: 369-387, 1971.

29) Urbach H, Scheffler B, Heinrichsmeier T, von Oertzen J, Kral T, Wellmer J, Schramm J, Wiestler OD, Blümcke I: Focal cortical dysplasia of Taylor's balloon cell type: A clinicopathological entity with characteristic neuroimaging 
and histopathological features, and favorable postsurgical outcome. Epilepsia 43:33-40, 2002.

30) Widdess-Walsh P, Diehl B, Najm I: Neuroimaging of focal cortical dysplasia. J Neuroimaging $\quad$ 16:185-196, 2006.
31) Widdess-Walsh P, Kellinghaus C, Jeha L, Kotagal P, Prayson R, Bingaman W, Najm IM : Electro-clinical and imaging characteristics of focal cortical dysplasia: Correlation with pathological subtypes. Epilepsy Res 67:25-33, 2005.

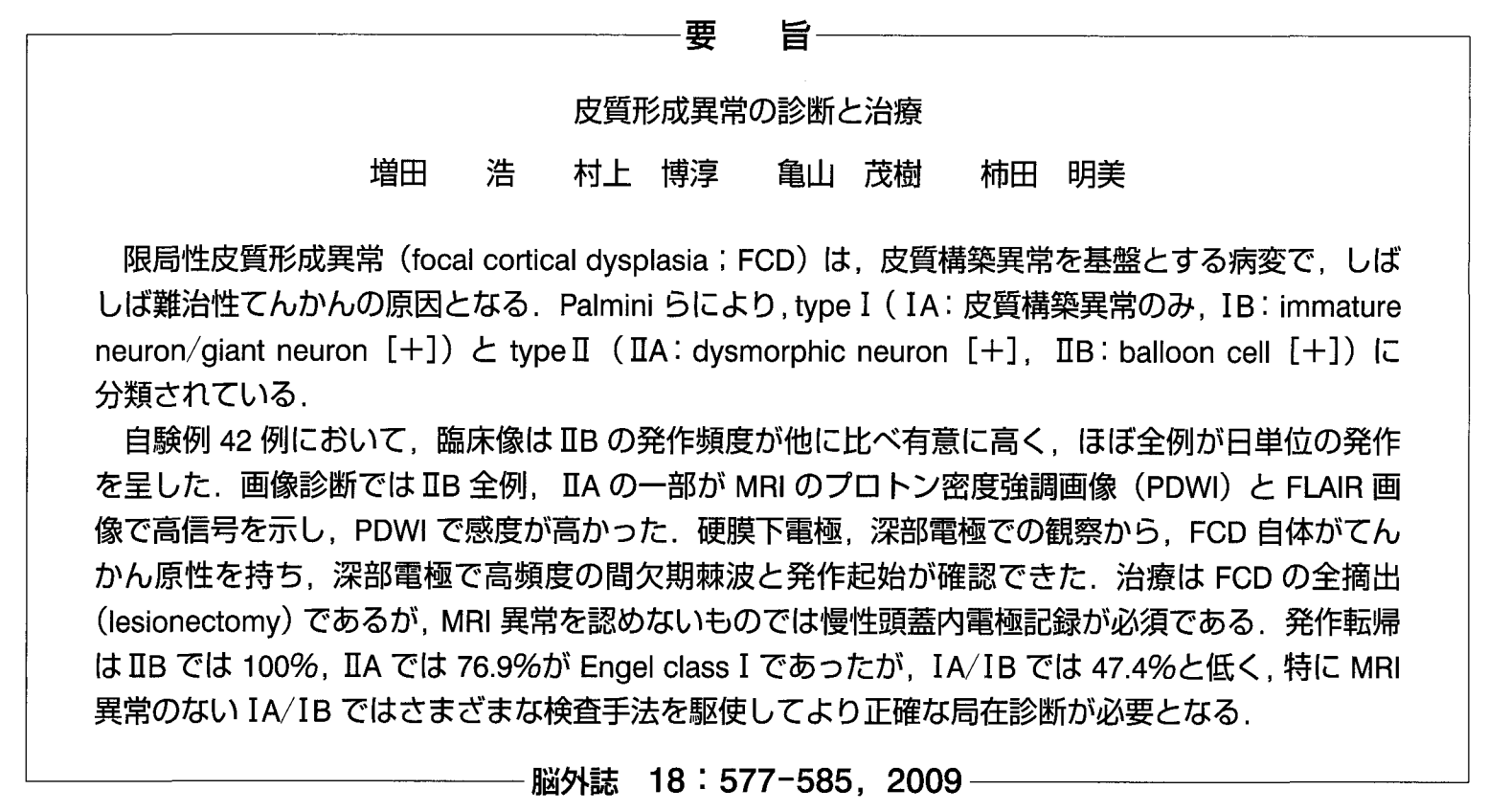

